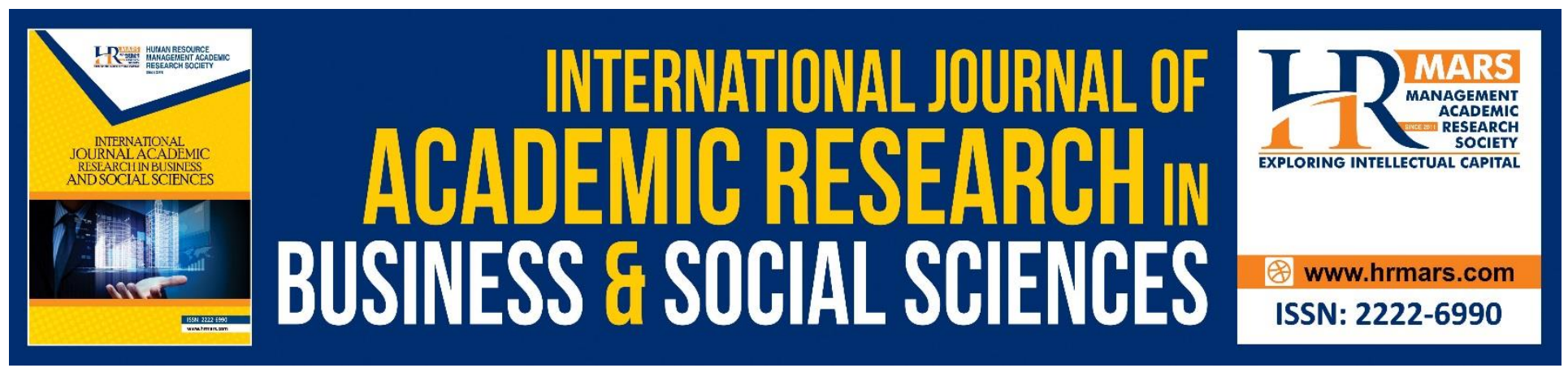

\title{
The Source of Al-Nasikh and Al-Mansukh (Abrogater and Abrogated) in Tafsir Nur al-Ihsam. An Intertextuality Study
}

Mohd Sholeh Sheh Yusuff, Yusuf Haji-Othman, Mat Rani Abdul Manaf

To Link this Article: http://dx.doi.org/10.6007/IJARBSS/v8-i10/4781

DOI: $10.6007 /$ IJARBSS/v8-i10/4781

Received: 17 Sept 2018, Revised: 21 Oct 2018, Accepted: 23 Oct 2018

Published Online: 28 October 2018

In-Text Citation: (Yusuff, Haji-Othman, \& Manaf, 2018)

To Cite this Article: Yusuff, M. S. S., Haji-Othman, Y., \& Manaf, M. R. A. (2018). The Source of Al-Nasikh and AlMansukh (Abrogater and Abrogated) in Tafsir Nur al-Ihsan: An Intertextuality Study. International Journal of Academic Research in Business and Social Sciences, 8(10), 813-823.

Copyright: (C) 2018 The Author(s)

Published by Human Resource Management Academic Research Society (www.hrmars.com)

This article is published under the Creative Commons Attribution (CC BY 4.0) license. Anyone may reproduce, distribute, translate and create derivative works of this article (for both commercial and non-commercial purposes), subject to full attribution to the original publication and authors. The full terms of this license may be seen

at: http://creativecommons.org/licences/by/4.0/legalcode

Vol. 8, No. 10, 2018, Pg. 813 - 823

http://hrmars.com/index.php/pages/detail/IJARBSS

JOURNAL HOMEPAGE

Full Terms \& Conditions of access and use can be found at http://hrmars.com/index.php/pages/detail/publication-ethics 


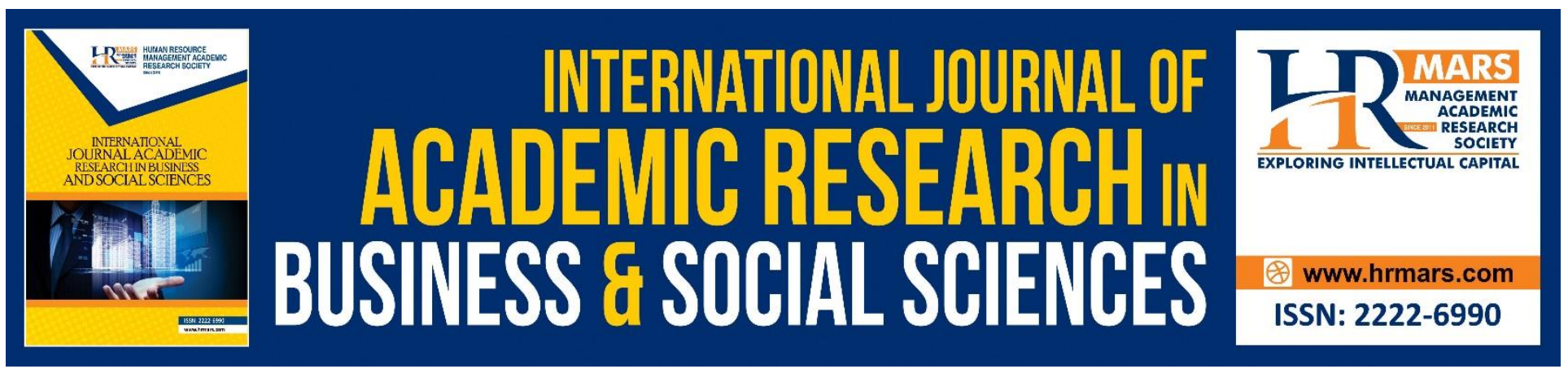

\title{
The Source of Al-Nasikh and Al-Mansukh (Abrogater and Abrogated) in Tafsir Nur al-Ihsarr. An Intertextuality Study
}

\section{Mohd Sholeh Sheh Yusuff ${ }^{1}$, Yusuf Haji-Othman², Mat Rani Abdul Manaf ${ }^{3}$}

${ }^{1,3}$ Kulliyyah of Usuluddin and Quranic Sciences, Sultan Abdul Halim Mua'dzam Shah International Islamic University, 09300 Kuala Ketil, Kedah, Malaysia

${ }^{2}$ Kulliyyah of Muamalat and Management Sciences, Sultan Abdul Halim Mua'dzam Shah International Islamic University, 09300 Kuala Ketil, Kedah, Malaysia

\begin{abstract}
Tafsir Nur al-Ihsan is the second interpretation after Tarjuman al-Mustafid written in the Malay language in the 19th century AD by Omar (1970). The main objective of this study is to identify the influence of the external source in the text of Tafsir Nur al-Ihsan about Al-Nasikh and Al-Mansukh (Abrogater and Abrogated). Intertextual reading method is used in the process of analyzing Tafsir Nur al-Ihsan founded by Bakhtin and descriptions, developed and analyzed by Krestiva (1980). This study employs library research and field work using the subjective approach which are descriptive and qualitative data. The study found three works which have influenced the essence of Al-Nasikh and Al-Mansukh (Abrogater and Abrogated), which are Tafsir al-Jalalyn, Tafsir al-Jamal and Tafsir alKhazin. The finding analysis also shows that Tafsir Nur al-Ihsan is mostly influenced by Tafsir alJalalyn.
\end{abstract}

Keyword: Tafsir Nur al-Ihsan; Al-Nasikh and Al-Mansukh; Intertextuality Study; intertextuality principle

\section{Introduction}

The writings of Islamic works and translations into Malay language have grown tremendously since the coming of Islam to Nusantara regions (Malaysia, Thailand, Brunei and Indonesia), which have covered various fields and branches of knowledge such as fiqh, aqidah, tafsir, hadith and sufism, among others. The writings and translations by previous Islamic scholars remain as important sources of reference and are still used by contemporary scholars for academic purposes. It proves the success of previous scholars who produced writings which have not only atrracted the interest of the public 
INTERNATIONAL JOURNAL OF ACADEMIC RESEARCH IN BUSINESS AND SOCIAL SCIENCES Vol. 8, No. 10, Oct. 2018, E-ISSN: 2222-6990 ㄷ 2018 HRMARS

but also have benefited them. One of the scholars is Omar, M. S. who produced a book in the field of tafsir in Malay language entitled Tafsir Nur al-Ihsan in 1970

Tafsir Nur al-Ihsan has been used as a reference in understanding Qur'anic verses not only by public but also contemporary scholars who have used it as a teaching material. This invaluable piece of work have given contribution to knowledge of the public at large so much so that scholars are attracted to study and examine this work from various aspects such as history, language, the influence and stature of the author.

Tafsir Nur al-Ihsan is also one of the books on tafsir al-Qur'an which is still being used as a teaching material and reference today especially at pondok institutions, mosques and musollas. Pondok institutions such as Pondok Tuan Guru Haji Bakar at Parit Panjang, Baling, Kedah, Malaysia and Pondok Tuan Guru Haji Soleh Musa at Sik, Kedah, Malaysia have been using the book as the teaching material for their weekly teaching. However, there have been criticisms on the content of Tafsir Nur al-Ihsan by certain sections of the public. Some of them opined that this book has its shortcomings because in the writing of this book, the author does not mention any citation and uses many unjustified opinion in his tafsir (Zaim, 2010), so much so that Muhammad Ismi stressed that the public should be careful when reading Tafsir Nur al-Ihsan (Mat Taib, 2003).

The motivation of this study is to make effort to help overcome the shortcoming of this invaluable piece of work by refining sources of reference and interconnections between the original text and other tafsir texts using intertextual reading. Since Tafsir Nur al-Ihsan has been used as a teaching material in the tafsir al-Qur'an and a reference by public at large in understanding verses of al-Qur'an, then efforts to refine this piece of work should be made. This will answer the aforementioned problem statement. The objective of this study is to examine Tafsir Nur al-Ihsan in order to examine whether there exists influence of other texts on the text of Tafsir Nur al-Ihsan using intertextual reading. This study focuses on Al-Nasikh and Al-Mansukh (Abrogater and Abrogated) on the text of Tafsir Nur al-Ihsan as an early effort towards refinement of the text which contributes to improve the invaluable work. Since the author of Tafsir Nur al-Ihsan mentioned that he referred to works in the field of tafsir while in the proces of writing (Omar, 1970), this study focuses only on tafsir works. This study employs library research and field study using subjective approach to examine data descriptively and qualitatively. The contribution of this study to shed some lights on the shortcomings of Tafsir Nur al-Ihsan so that teachers and students using this book as a reference are made aware of it and able to find the truth by referring to the original sources.

\section{Intertextual Reading Method}

Intertextual reading method was originally known as dialogic which was introduced by Bakhtin in the year 1926 because there were voluminious Russian art literatures which were difficult to comprehend at that time. As a consequence, this theory was introduced by Bakhtin in order to facilitate readers to understand the difficult literatures. This theory pictured that all literatures which 
were written were based on dialogues between one text and another. In other words, this theory states that any text is influenced by other texts. This is supported by Harari (1979), who mentioned that "every text, being itself the intertext of another text, belong to the intertextual, which must not be confused with a text's origins".

The basis of this dialogic theory is used to understand Dostoyevsky's literatures such as The Gambler, The Idiot and The Brother's Karamazovwhich were considered as difficult to be understood by public using theories of literature such as formalisme which were dominant during that time (Dostoyevsky, 1975). The Russian formalism approach which was on the rise during that time did not help the public to understand approach of Dostoyevsky's literature. Bakhtin's dialogisme emphasized external aspect which influenced reading or how an author approached art literatures and in turn would flow naturally into his own literature writing. However, Bakhtin did not deny the importance of internal elements such as theme, thought, plot, characters and other elements.

In the theory of dialogisme, an author would have a dialogue with the text itself, himself and readers. This would create dialogues between a text and another text and as a consequence, it would trigger changes, conflicts and expansion in the literature which was being written by the author in terms of theme and problems, plot or characters and characterization. Therefore, connection between external and internal structures in a literature is important in this approach. According to Schmitz (2007), sentences used by someone in speech or writing interconnects among them and if there is no dependency among them, then any sentence or speech becomes gloomy and inexpendable. Schmitz (2007) mentioned;

"Language always works within certain situations, and utterances produce their significance within thin context. The linguistic material alone is not enough to determine whether a word or a sound is enthusiastic, gloomy, ironical, threatening, or deferential; rather, this depends on a number of factors such as intonation, volume, the interlocutor, and prior utterances in the dialogue"(Schmitz 2007, 66-67).

This theory was later discussed by Kristeva (1980) who did not name this theory as dialogic, instead, she termed it as intertextuality. Hawthorn (2000) mentioned that every text written is influenced by other texts and this influence is discussed in intertextual theory. Therefore, readers should not be confused with the original text which is the hipogram of a given text. Jeremy Hawthorn (2000) stated that "Kristeva defines the text as a permutation of texs, an intertext in the space of a given text...".

The development of this theory not only have taken place in Europe but also in the whole worldwide. In Southeast Asia, it has been discussed as one of modern literary theory in which one scholar in the field of literature named Partini Sardjono has developed this theory. He has not only stood on the principles of Kristeva, but has also introduced another principle termed as excerpt. This principle applies when a text incarnated in another text in an abstract form. Subsequently, there was the birth of new names in Indonesia such as Teeuw and Omar. Meanwhile, in Malaysia and Singapore, it became known after Napiah (1989) discussed in several books, particularly in his PhD thesis entitled 
INTERNATIONAL JOURNAL OF ACADEMIC RESEARCH IN BUSINESS AND SOCIAL SCIENCES

Vol. 8, No. 10, Oct. 2018, E-ISSN: 2222-6990 ㄷ 2018 HRMARS

"Tuah Jebat in Malay Drama: A Study of intertextuality". In this thesis, he not only discussed this theory at length, but also applied it to the book entitled Hikayat Hang Tuah (Wan Nasyrudin, 2008).

\section{Principles in Intertextual Reading Method}

Based on Kristeva (1980) and Sardjono (1986), there are 10 intertextual principles which have often appeared in literature and manifestation reflected in a person's style of writing, namely:

a. Transformation.

Transformation refers to either a formal or abstract transfer, transformation or conversion of a text to another text (Kristeva 1980, 80).

b. Modification principle.

Modification principle occurs when the author makes adjustments, changes or amendments on certain text in a given text. This principle occurs due to the desire of the author to retrieve or replicate a text into another text and adjusts it according to the wants of society, culture, politics and readers' minds (Kristeva 1980, 90).

c. Expansion.

Expansion occurs when an author expands or develops a text. For example, a short story is developed by an author until it becomes a complete novel (Kristeva 1980, 90).

d. Demitefication.

Demitefication is a contradiction to the meaning of a text which appeared in earlier work. The author questioned the text before making contradiction (Kristeva 1980, 103).

e. Haplology.

Haplology occurs when there are omissions upon the presence of texts into other texts. This process occurs during selection and editing process for the purpose of making text adjustments in order to harmonize the work (Kristeva 1980, 25).

\section{f. Excerpt.}

Excerpt happens when the text is the same as or perhaps similar to some essence, a quote, an episode or aspect of hipogram or the original text (Sardjono 1986, 63).

\section{g. Parallel.}

Parallel occurs when there similarities or parallels between a text and other text(s) in terms of theme, idea or form of the text itself. Parallel Principles shows elements of parallelism and alignment of text within a text. However, the author should cite the source of the text so that it is not considered as plagiarism (Kristeva 1980, 91). 
INTERNATIONAL JOURNAL OF ACADEMIC RESEARCH IN BUSINESS AND SOCIAL SCIENCES Vol. 8, No. 10, Oct. 2018, E-ISSN: 2222-6990 ㄷ 2018 HRMARS

\section{h. Conversion.}

Conversion happens when there is a distortion of the original text or hipogram or contradiction to the taken text. This resistance element is not the same as those in the demitefication principle. In fact, it is not so radical and does not undergo aggressive or drastic changes (Kristeva 1980, 107).

\section{i. Existence.}

Existence occurs when elements created or organized in a work is distinctly different from its hypogram text. This process occurs when the author conducts a renewal of major works that form the basis of his/her writing (Kristeva 1980, 106-107).

\section{j. Defamiliarization.}

Defamiliarization is an extraordinary element in a certain piece of work. It means the effort of an author to bring extraordinary elements by making changes to the text such as changes in terms of meaning or role played by a particular character in the piece of work (Kristeva 1980, 131).

Each of these principles does not have to appear separately in a certain work, which means that some of them could appear simultaneously. For example, when a particular text goes through a transformation process, it could also pass through modification process, expansion or any other intertextual principles at the same time.

\section{Tafsir Nur Al-Ihsan: An Introduction}

Tafsir Nur al-Ihsan is a well-known works that have been produced by Omar (1970). Writing this work was time consuming for it took two years nine months to complete, and it was successfully completed on $1^{\text {st }}$ of October 1927 (Omar, 1970). This work is one of the works in the fields of tafsir al-Quran of the earliest produced in the Malay world after Tarjuman al-Mustafid by Sheikh Abdul Rauf al-Singkeli in the 17th century (Wan Nasyrudin, 2008).

Tafsir Nur al-Ihsan began to be printed by the first print in 1934 in Mecca by Maktabah wa Matbaah Muhammad al-Nahdi wa Awladih and second print was in the year of 1936 in Penang. The third printing of the work was in the year 1391 Hijrah equivalent to 1970 by al-Muarif Sdn. Bhd, Matba'ah bin Halabi in Fathani and Matbaah Muhammad al-Nahdi wa Awladih in Bangkok, Thailand. Meanwhile, there is also a print published by Dar al-Ihya' al-Kutub al-Arabiyyah, Egypt in the year 1349 Hijrah. Each print of Tafsir Nur al-Ihsan must first obtained the consent of the heirs of Omarand signature of the permission can be seen on each page per volume (Haji Othman, 2012).

Tafsir Nur al-Ihsan produced by Omar (1970) came in four volumes and each volume is sorted according to the chapters (surah) of al-Quran. The first volume covers the Surah al-Fatihah to alMaidah, the second volume covers al-An'am to Surah Hud, third volume includes Surah al-Kahf to alZumar, and the fourth volume covers al-Mukmin to Surah al-Nas. Tafsir Nur al-Ihsan is quite difficult to be obtained on the market and it is only sold in certain bookstores only. Most of the works circulating in the market these days is printed by the company from Bangkok measuring $26.5 \mathrm{~cm} \times 20$ $\mathrm{cm}$. 
This work iswidely spread particularly in the State of Kedah, Malaysia and even in Northern Perak, Penang and Seberang Prai, Malaysia also in southern Thailand (Abdul Rahman, 2010). Tafsir Nur alIhsan is a work in the fields of tafsir al-Quran in the Malay language written using Jawi which has given many benefits to the Muslims, especially in Malaysia, while it is also a best-effort made by Omar (1970) thath as been passed on to the community until today. The content of this work is complete and comprehensive accounting for description of the contexts and occasions of the revelation of the Quran, the virtues of surah and verse, problems of Figh, al-Mutashabihat, al-Nasikh and al-Mansukh plus stories of previous generations.

\section{Al-Nasikh and Al-Mansukh (Abrogater and Abrogated) in Tafsir Nur Al-Ihsan}

Naskh (نسخ) is an Arabic word usually translated as "abrogation"; It refers to the theory in Islamic legal exegesis whereby seemingly contradictory material within, or between, the two primary sources of Islamic law (the Quran and the Sunnah) are resolved by superseding or canceling the earlier revelation (Zaydan, 1996). Several Qur'anic verses state that some revelations have been abrogated and superseded by later revelations, which are understood by many Muslim scholars as pertaining to the verses of the Quran itself. Some examples include a gradual ban on consumption of alcohol and a change in qibla (the direction someone praying salat should face) from Jerusalem to Mecca. According to Atar (1996), the scholars divide al-Nasikh and al-Mansukh into five divisions namely the law which has been replaced but the verse with respect to it is retained, the verse on a matter replaced by another verse, the Qur'anic verse is repealed by the al-Hadith, the verse repealed along with his law and the abrogated verse, but the law was still executed.

In the Tafsir Nur Al-Ihsan, when the author discusses the verse relating to al-Nasikh and al-Mansukh, he will say whether the verse is al-Nasikh or al-Mansukh. There are 28 places where the author speaks about this, which is 12 places in the first volume, four places in the second volume, two places in the third volume and 10 places in the fourth volume. The author uses 14 expressions ie; This is the law of mansukh, because mansukh and this verse mansukh. For example, the authors state that the law does not have to fight against unbelievers who refuse to fight the Muslims: "when the Unbelievers do not want to fight with you, do not fight them. This verse mansukh with the verse al-Sayf" (Omar, 1970).

The Analysis of Intertextual on Al-Nasikh and Al-Mansukh (Abrogater and Abrogated) in Tafsir Nur al-Ihsan

Table 1 below is obtained as a result of review content of Tafsir Nur al-Ihsan as a whole pertaining of Al-Nasikh and Al-Mansukh (Abrogater and Abrogated). Results analysis found that the works that have been referred by the author when telling about Al-Nasikh and Al-Mansukh (Abrogater and Abrogated) in Tafsir Nur al-Ihsan is Tafsir al-Jalalyn, Tafsir al-Jamal and Tafsir al-Khazin. In addition, the principle of the intertextual principles used comprised of parallel, excerp, haplology and expansion principles. 
INTERNATIONAL JOURNAL OF ACADEMIC RESEARCH IN BUSINESS AND SOCIAL SCIENCES Vol. 8, No. 10, Oct. 2018, E-ISSN: 2222-6990 @ 2018 HRMARS

Table 1: The List of Reference Works of Al-Nasikh and Al-Mansukh (Abrogater and Abrogated) in Tafsir Nur al-Ihsan and Intertextual Principles

\begin{tabular}{ccccccc}
\hline No. & Works & Parallel & Excerp & Haplology & Expansion & Total \\
\hline 1 & Tafsir al-Jalalyn & 13 & 11 & 3 & 4 & $\mathbf{3 1}$ \\
2 & Tafsir al-Jamal & 0 & 3 & 3 & 0 & $\mathbf{6}$ \\
3 & Tafsir al-Khazin & 0 & 1 & 0 & 0 & $\mathbf{1}$ \\
\hline & & $\mathbf{1 3}$ & $\mathbf{1 5}$ & $\mathbf{6}$ & $\mathbf{4}$ & $\mathbf{3 8}$ \\
\hline
\end{tabular}

The Works Influencing the Al-Nasikh and Al-Mansukh (Abrogater and Abrogated) in Tafsir Nur alIhsan

Table 2 shows the data that has been analyzed and the finding shows that text from Tafsir al-Jalalyn has influenced Al-Nasikh and Al-Mansukh (Abrogater and Abrogated) in Tafsir Nur al-Ihsan of 24 times (86\%), Tafsir al-Jamal three times (11\%) and Tafsir al-Khazin once (6\%) respectively. Therefore, this article proves that the work most widely referred to by Sheikh Muhammad Said relevant of AlNasikh and Al-Mansukh (Abrogater and Abrogated) while writing Tafsir Nur al-Ihsan is Tafsir alJalalyn.

Table 2: List of Works Referred to on the Al-Nasikh and Al-Mansukh (Abrogater and Abrogated) in Tafsir Nur al-Ihsan.

\begin{tabular}{clccc}
\hline No. & Title of Works & Frequency & Percentage \\
\hline 1 & Tafsir al-Jalalyn & 24 & $86 \%$ \\
2 & Tafsir al-Jamal & 3 & $11 \%$ \\
3 & Tafsir al-Khazin & 1 & $6 \%$ \\
\hline & & $\mathbf{2 8}$ & $\mathbf{1 0 0 \%}$ \\
\hline
\end{tabular}

Principles in Intertextual Used

Table 3 reveals the principles of intertextual approach used by the author when he narrates the AlNasikh and Al-Mansukh (Abrogater and Abrogated) in Tafsir Nur al-Ihsan.

Table 3: Principles in Intertextual Used

\begin{tabular}{clccccc}
\hline No. & Analysis & Parallel & Excerp & Haplology & Expansion & Total \\
\hline 1 & Al-Nasikh and Al-Mansukh & 13 & 15 & 6 & 4 & 38 \\
\hline Percentage & $34.2 \%$ & $39.4 \%$ & $15.7 \%$ & $10.5 \%$ & $100 \%$ \\
\hline
\end{tabular}

Table 3 indicates that there are four principles of intertextual approach used when the author narrates the Al-Nasikh and Al-Mansukh (Abrogater and Abrogated) in Tafsir Nur al-Ihsan, which indicate 13 times of parallel (34.2\%), 15 times of excerp (39.4\%), 6 times of Haplology (15.7\%) and 
INTERNATIONAL JOURNAL OF ACADEMIC RESEARCH IN BUSINESS AND SOCIAL SCIENCES

Vol. 8, No. 10, Oct. 2018, E-ISSN: 2222-6990 C 2018 HRMARS

four times of Expansion (10.5\%), which makes the principles most frequently used the author is excerp principle.

\section{Conclusion}

Based on the study, this article concludes the following;

1. Intertextual approach has its own method. This method combines the process of processing, construction and digestion of two aspects, namely, the internal and external aspects that build a masterpiece. Internal aspect is showed when the author set a style of interpretation in itself, while the external aspect is when other works exist that affect the text.

2. Tafsir Nur al-Ihsan is a work in the field of tafsir al-Quran produced by Omar (1970). This work received widespread recognition not only in Malaysia but also in Indonesia, Egypt and Thailand on par with other contemporary exegesis. What is interesting about this work is its simple style which easily understood by society and also provide of a variety of knowledge. In language style that's easy to the needs of all levels of society and appropriate use by modern civil society such as Malaysia.

3. Omar (1970) has referred three of famed works i.e. Tafsir al-Jalalyn, Tafsir al-Jamal and Tafsir al-Khazin when debating 28 of Al-Nasikh and Al-Mansukh (Abrogater and Abrogated) which are very interesting for society to learn. Through this study, sources of references for all the Al-Nasikh and Al-Mansukh (Abrogater and Abrogated) are able to be identified. Therefore, this study finds that Omar (1970) not only used the unfounded facts but alsohis own opinions in the writing of Tafsir Nur al-Ihsan.

4. This study provides evidence that the main reference work of the author concerning the AlNasikh and Al-Mansukh (Abrogater and Abrogated) in Tafsir Nur al-Ihsan was Tafsir al-Jalalyn based on the percentage of frequency used by Omar (1970) which indicates that Tafsir alJalalyn was the work which he referred to the most. While the Tafsir al-Jamal and Tafsir alKhazin were its ancillary reference works. In addition, the principle of intertextual which was the most widely used was excerp principle.

This study contributes to the knowledge in the area of Quranic Sciences by shedding some lights on and overcoming the shortcomings of Tafsir Nur al-Ihsan by identifying the influence of the external source in the text of Tafsir Nur al-Ihsan about Al-Nasikh and Al-Mansukh (Abrogater and Abrogated). Besides, this study is able to provide evidence that there exists influence of other texts on the text of Tafsir Nur al-Ihsan using intertextual reading. In addition, by refining the the shortcomings of Tafsir Nur al-Ihsan, this study contributes to the religious institutions which have been using Tafsir Nur alIhsan as a teaching material, and the public at large because this book has been used as a teaching material in the tafsir al-Qur'an and a reference by public at large in understanding verses of al-Qur'an .

\section{References}

Abdul Rahman, A. R. (2010). Mengenali Tuan Haji Saaid Mufti Ulama Tersohor di Alam Melayu. Working Paper at Seminar Ulama Melayu. Shah Alam.

Abdul Razak, H. O. (2012). Riwayat Hidup Syeikh Muhammad Sa'id. Alor Setar. Interview. 
INTERNATIONAL JOURNAL OF ACADEMIC RESEARCH IN BUSINESS AND SOCIAL SCIENCES

Vol. 8, No. 10, Oct. 2018, E-ISSN: 2222-6990 (C) 2018 HRMARS

Al-Dhahabi, M.H. (1977). 'Ilm Al-Tafsir. Cairo: Dar al-Ma'arif.

Al-Jamal, S. (2013).Tafsir al-Jamal. Beirut: Dar al-Kutub al-'Ilmiyyah.

Al-Khazin, A.A. (2010). Tafsir Al-Khazin. Beirut: Dar al-Kutub al-'Ilmiyyah.

Al-Suyuti \& Al-Mahalli. (2010). Tafsir Al-Jalalyn. Beirut: Dar al-Kutub al-'Ilmiyyah.

Atar, N. D. (1996). Ulum al-Qur'an al-Karim. Dimashq: Dar al Subl.

Dostoyevsky, F. (1965). The Idiot: Transl. with an Introd. by David Magarshack. Penguin Books.

Fadlan, M. O. (2009). Aplikasi Ilmu Takhrij Dalam Kitab Tafsir Melayu: Tinjauan Awal Terhadap Surah Al-Baqarah, Kitab Tafsir Nur Al-Ihsan Oleh Al-Shaykh Muhammad Sa'id Bin 'Umar. Working paper at Seminar Sehari Tokoh Tafsir Dunia Melayu. UNITEN.

Ibn Khaldun, A. M. (2000). Muqaddimah Ibn Khaldun. Beirut: Dar Sadir.

Ibn Kathir, A. U. (1999). Tafsir Al-Qur'an Al-Azim. Al-Riyad: Dar Tayyibah.

Hawthorn, J. (2000). A Concise Glossary of Contemporary Literary Theory. London: Arnold.

Harari, J.V. (1979). Textual Strategies. New York: Cornell University Press.

Kristeva, J. (1980). Desire in Language: A Simeotik Approach to Literature and Art. Oxford: Basil Blackwell.

Mat Taib, M.I. (2003). Israiliyyat Dalam Tafsir: Kajian Terhadap Kitab Nur al-Ihsan, Karya Haji Muhammad Sa'id bin 'Omar. Master Thesis. University of Malaya.

Omar, M.S. (1970). Tafsir Nur al-Ihsan. Fatani: Matba'ah Bin Halabi.

Sardjono, P. (1986). Kakawin Gajah Mada. Bandung: Penerbit Binacipta.

Schmitz, T. A. (2007). Modern Literary Theory and Ancient Texts: An Introduction. Victoria. Blackwell Publishing.

Wan Nasyrudin, W.A. (2008). Tafsir Tarjuman al-Mustafid: Kajian Intertekstual. PhDThesis, University of Malaya.

Zaydan, A. K. (1996M) Al-Wajiz fi Usul al-Fiqh. Beirut: Mu'assasah al-Risalah. 
INTERNATIONAL JOURNAL OF ACADEMIC RESEARCH IN BUSINESS AND SOCIAL SCIENCES

Vol. 8, No. 10, Oct. 2018, E-ISSN: 2222-6990 @ 2018 HRMARS

Zaim, M.N. (2010). Kajian Takhrij Hadith Dalam Tafsir Nur Al-Ihsan. Master Thesis. Universiti Sains Malaysia. 